\title{
Peran Mahasiswa Dalam Pencegahan Bencana Asap Melalui Kukerta Terintegrasi Universitas Abdurrab di Desa Dayun
}

\author{
Diki Arisandi' ${ }^{1}$ Amir Syamsuadi², Seri Hartati*3, Liza Trisnawati ${ }^{4}$ \\ 1,2,3,4 Program Studi Ilmu Pemerintahan, Fakultas Ilmu Sosial dan Politik, Universitas Abdurrab \\ *e-mail: seri.hartati@univrab.ac.id*3,diki@univrab.ac.id¹, amir.syamsuadi@univrab.ac.id² , \\ liza.trisnawati@univrab.ac.id ${ }^{4}$
}

\begin{abstract}
Dayun is one of the villages in the Siak Regency. Every year, the thread of fire and haze disaster always occurs and causes economic losses and health impairment of the villagers. This Community service was in partnership with the Regional Disaster Management Agency of Siak Regency. Through the integrated Community service program for the student of Abdurrab University, collaborating with the Lecturer's Community Service program, the students from various majors are taking action to the community service in Dayun Village. The activities were to transfer the knowledge to the community and designing an early detection system. During the program, the students were creating media designs such as videos and pamphlets. Some Informatics students were developing a web-based application for early detection. The results were presented at the Regional Disaster Management Agency of Siak Regency and acquired positive responses from the participants.
\end{abstract}

Keywords: Dayun, Community service program for student, Interactive media, early-detection application, Haze.

\begin{abstract}
Abstrak
Desa Dayun merupakan salah satu wilayah di Kabupaten Siak. Setiap tahun, bahaya kebakaran dan bencana asap selalu terjadi dan menimbulkan kerugian ekonomi dan mengganggu kesehatan bagi Masyarakat desa Dayun. Kegiatan pengabdian ini bermitra dengan Badan Penanggulangan Bencana (BPBD) Kabupaten Siak. Melalui kegiatan kuliah kerja nyata terintegrasi dengan kegiatan pengabdian Dosen Universitas Abdurrab, mahasiswa yang berasal dari berbagai bidang ilmu memberikan kontribusi kepada masyarakat di desa Dayun. Ada dua Kegiatan yang dilakukan dalam kegiatan ini diantaranya penyuluhan ke Masyarakat dan perancangan sistem deteksi dini. Beberapa karya mahasiswa KUKERTA diantaranya yaitu desain media berupa video dan pamflet, selain itu beberapa mahasiswa membuat aplikasi untuk deteksi dini berbasis web. Hasil kegiatan dipresentasikan di kantor BPBD Kabupaten Siak dan mendapat respon positif dari peserta yang hadir.
\end{abstract}

Kata kunci: Dayun, KUKERTA, Media, Aplikasi Deteksi Dini, Asap.

\section{PENDAHULUAN}

Dayun adalah salah satu kampung yang ada di kecamatan Dayun kabupaten Siak (Harahap, Yoza, \& Oktorini, 2017), yang berjarak $18 \mathrm{~km}$ dari ibu kota kabupaten siak, berjarak 116 km dari Ibu Kota Provinsi Riau, Pekanbaru (Badan Perencanaan Pembangunan Daerah Kabupaten Siak, 2014). Luas wilayah Dayun adalah 241.743 Ha dimana Geografi berupa daratan yang bertopografi datar sedang, dan 350 Ha daratan dimanfaatkan sebagai lahan pertanian (Nugraha, Fauzi, \& Ekayani, 2019). Sebagian besar masyarakat Dayun yaitu sebagian ada nelayan, pedagang, buruh harian, pekerja pada kebun karet dan kebun sawit (Naufal, Waluyati, \& Darwanto, 2019)

Kasus kebakaran yang terjadi di wilayah Siak, terutama Dayun umumnya berasal dari lahan perkebunan sawit (Syamsuadi et al., 2020). Animo masyarakat dalam menanam sawit di Riau termasuk daerah Siak sangat tinggi. Pada saat ini, lahan gambut yang tergolong lahan subur di daerah Dayun banyak yang berubah fungsi menjadi lahan sawit (Meiwanda, 2016). Kegiatan pembakaran lahan gambut untuk dijadikan perkebunan sawit menjadi solusi yang cepat dan murah walaupun efek dari asap yang timbul dapat mengganggu kesehatan dan aktivitas warga (Nasution, Mubarak, \& Zulkifli, 2013). Akibat persoalan yang ditimbulkan tersebut, banyak aktivitas sosial dan ekonomi warga yang terganggu. Dampak lain juga yang tidak kalah penting 
yaitu pada kesehatan warga, dimana daerah Kabupaten Siak merupakan wilayah yang termasuk dalam tiga besar daerah dengan penderita ISPA terbanyak di provinsi Riau (Saharjo et al., 2018). Informasi ini juga dibenarkan oleh Dinas Kesehatan Kabupaten Siak melalui media Riau Pos (Riau Pos, 2019), dimana pada tahun 2019 angka penderita ISPA sudah mencapai lebih dari empat ribu orang seperti terlihat pada gambar 1.
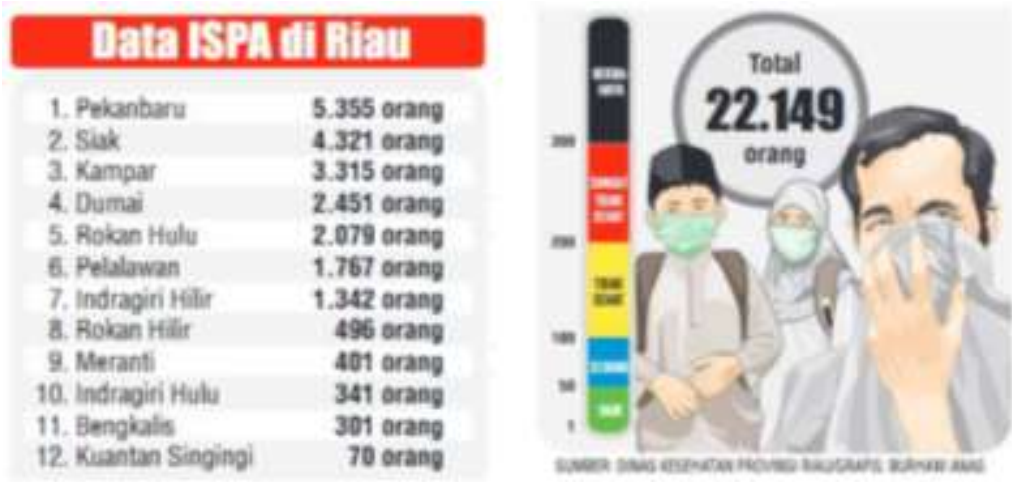

Gambar 1. Jumlah Penderita ISPA Tahun 2019

Persoalan kebakaran hutan di Kabupaten Siak, Khususnya Desa Dayun menjadi wilayah terdampak setiap tahun. Pembakaran lahan menjadi sebuah hal yang lazim diketahui oleh warga disekitar Dayun, hal ini juga disebabkan karena penegakan hukum yang belum maksimal (Jamaan, Yuliani, Adianto, \& Sadad, 2019). Selain itu, Penanganan bencana kebakaran yang timbul tiap tahun lebih banyak bersifat penanganan, bukan pencegahan. Penanganan yang dimaksud yaitu pemadaman yang dilakukan secara bergotong royong oleh Damkar yang dibantu oleh warga setempat dan MPA atau Masyarakat Peduli Api (Arisandi, Syamsuadi, Gafar, Hartati, \& Fajar, 2020a), serta dikoordinir oleh BPBD Kabupaten Siak (Friscalia, 2016).

Tindakan penanganan bencana perlu diiringi dengan tindakan pencegahan agar dapat menghasilkan hasil yang lebih maksimal. Pada era 4.0 saat ini, masyarakat terutama mahasiswa dituntut untuk bisa beradaptasi dan kreatif (Mustafa et al., 2020). Kegiatan KUKERTA (Kuliah Kerja Nyata) Mahasiswa yang diadakan oleh Universitas Abdurrab pada tahun 2020 ini mengintegrasikan KUKERTA dengan pengabdian yang dijalankan oleh Dosen. Tim pengabdi dari Dosen membimbing kegiatan mahasiswa melalui KUKERTA terintegrasi ini untuk memberikan usaha pencegahan bencana kebakaran kepada masyarakat di Desa Dayun. Mahasiswa yang terlibat berasal dari beberapa bidang Ilmu seperti Kedokteran, Ilmu Pemerintahan, dan Teknik Informatika. Masing-masing mahasiswa tersebut mengambil peran untuk ikut serta, peduli, dan kreatif dalam menghadapi bencana asap dengan membuat karya yang bisa disebarluaskan kepada masyarakat Desa Dayun berdasarkan disiplin ilmunya diantaranya pembuatan media berupa video dan pamflet terkait dengan bahaya kebakaran, larangan pembakaran hutan, dan dampak kebakaran bagi kesehatan. Selain itu, beberapa mahasiswa dari program studi teknik informatika merancang sebuah aplikasi pemantau kondisi lahan gambut yang terintegrasi dengan perangkat telemetri hasil pengabdian Dosen (Arisandi, Syamsuadi, Gafar, Hartati, \& Fajar, 2020b), yang mana aplikasi ini dapat dimanfaatkan oleh BPBD dan perangkat Desa sebagai sarana pengambilan tindakan sebelum kebakaran lahan terjadi.

Selain dapat membantu Dosen dalam menjalankan tugas pengabdian, kegiatan KUKERTA dapat mengasah kemampuan mahasiswa untuk dapat melihat permasalahan yang sedang terjadi ditengah Masyarakat, sekaligus memberikan Solusi pemecahannya berdasakan disiplin ilmu yang telah dipelajari selama dibangku perkuliahan (Sutisna, Hikmatin, \& Utami, 2018). Sehingga setelah menyelesaikan perkuliahan, mahasiswa dapat menjadi sosok yang mampu menjadi agen perubahan ditengah-tengah Masyarakat sesuai dengan keilmuan yang dimiliki. 


\section{METODE}

Metode yang dilaksakan dalam kegiatan KUKERTA yang terintegrasi dengan pengabdian masyarakat terdiri dari beberapa tahap, diantaranya adalah:

\section{Persiapan}

Kegiatan persiapan yang dilakukan mahasiswa dalam KUKERTA terintegrasi diantaranya mencakup mengidentifikasi permasalahan apa saja yang terjadi dan mencari alternatif solusi, observasi tempat KUKERTA, Pengurusan izin kegiatan ke pihak Mitra Pengabdian, pendataan peserta yang dibantu oleh pihak Desa, pengadaan kebutuhan acara, dan menyusun timeline kegiatan. Kegiatan persiapan dilanjutkan dengan melakukan identifikasi dengan melakukan wawancara kepada pihak terkait seperti BPBD Kabupaten Siak, pemerintah Desa Dayun, dan ketua Masyarakat Peduli Api (MPA) Desa Dayun. Salah satu masalah yang terindentifikasi oleh mahasiswa yaitu kurangnya kesadaran akan bahaya yang ditimbulkan oleh asap pada saat terjadi kebakaran, sehingga menyebabkan tingginya angka penderita ISPA di Siak, termasuk daerah Dayun. Selain kurangnya kesadaran, mahasiswa juga mengidentifikasi bahwa adanya kebutuhan terkait sistem pemantauan dini kondisi lahan gambut yang bisa diakses dengan menggunakan internet, sehingga dapat diakses oleh pihak terkait.

\section{Pelaksanaan}

Kegiatan pelaksanaan KUKERTA berfokus kepada upaya pencegahan, yaitu pemberian edukasi kepada masyarakat melalui media seperti video maupun pamflet. Mahasiswa yang berasal dari Kedokteran membuat karya berupa media tentang bahaya yang ditimbulkan oleh asap dari segi kesehatan, tingkatan kadar bahaya asap, bagaimana pengobatan pertama ketika terpapar asap, ajakan agar tidak membakar lahan serta membantu mitra untuk menjaga kelestarian hutan. Mahasiwa yang berasal dari Ilmu Pemerintahan membuat desain media yang memuat dasar hukum larangan pembakaran hutan dan sanksi yang dikenakan bagi yang melakukan, dan juga ajakan untuk melakukan penghijauan pada lahan yang ditinggalkan. Sedangkan mahasiswa yang berasal dari Teknik Informatika bertugas membantu Dosen untuk membuat rancangan antarmuka aplikasi deteksi dini berbasis web yang terhubung dengan alat telemetri yang sudah dipasang pada tiga titik lahan di desa Dayun, diantaranya lahan gambut yang bersebelahan dengan hutan lidung, lahan gambut yang terbengkalai, dan lahan gambut yang memiliki sedikit sumber air. Harapannya dengan adanya antar muka ini, pihak desa maupun BPBD dapat memperoleh informasi sejak dini sebelum terjadi bencana asap dan juga mengambil tindakan pencegahan, seperti status kelembapan tanah, kelembapan udara, suhu, dan keberadaan asap.

\section{Evaluasi}

Setelah kegiatan pengabdian selesai dilaksakanan, tim pengabdian beserta dengan mahasiswa KUKERTA akan mengadakan evaluasi sederhana berupa penyebaran angket kepada beberapa masyarakat desa Dayun, pihak desa, dan pihak BPBD untuk mengetahui sejauh mana pemahaman dan kepuasan atas kegiatan yang telah dilaksakanan. Tentunya hasil survey ini dapat menjadi tolok ukur keberhasilan dan juga evaluasi untuk kegiatan KUKERTA maupun pengabdian selanjutnya.

\section{HASIL DAN PEMBAHASAN}

Kegiatan awal pengabdian diawalai dengan melakukan pertemuan dengan BPBD Kabupaten Siak sebagai mitra kegiatan seperti terlihat di gambar 2a. Pertemuan ini dimaksud untuk meminta izin terkait kegiatan pengabdian dan mendapatkan informasi yang berkaitan dengan bencana asap didaerah desa Dayun. Kemudian kegiatan awal dilanjutkan dengan mengunjungi desa Dayun untuk mendapatkan gambaran lebih jelas tentang bencana asap 
sekaligus menginformasikan kepada Kepala Desa Dayun tentang kegiatan pengabdian dan KUKERTA ini (gambar 2b).

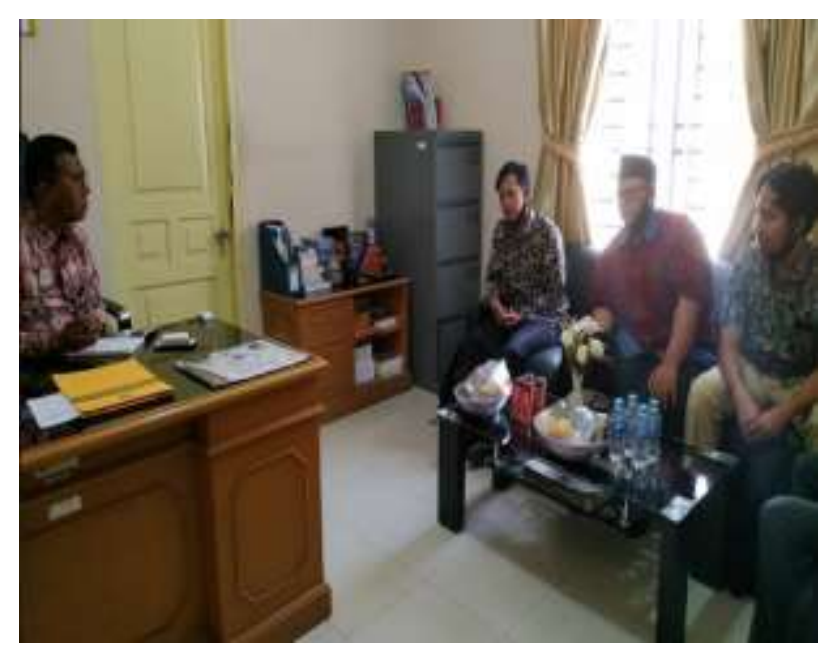

(a)

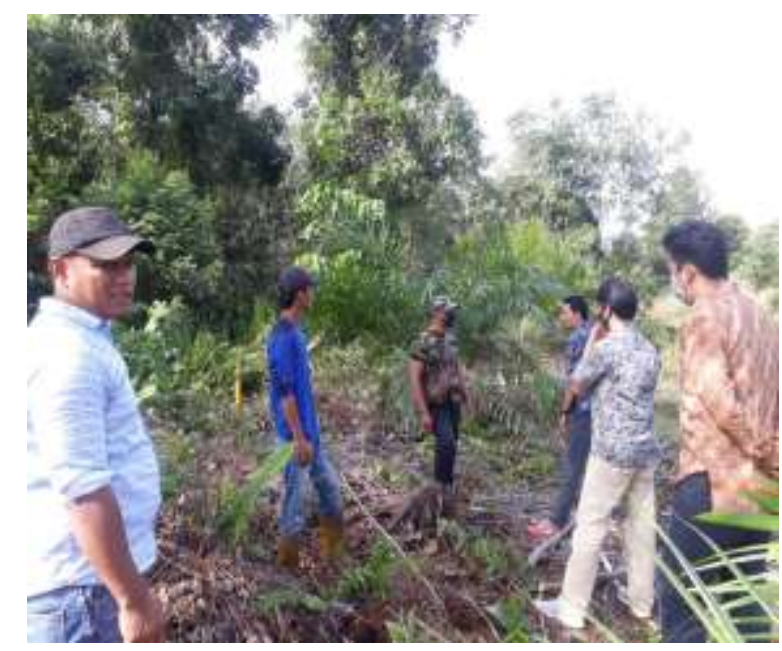

(b)

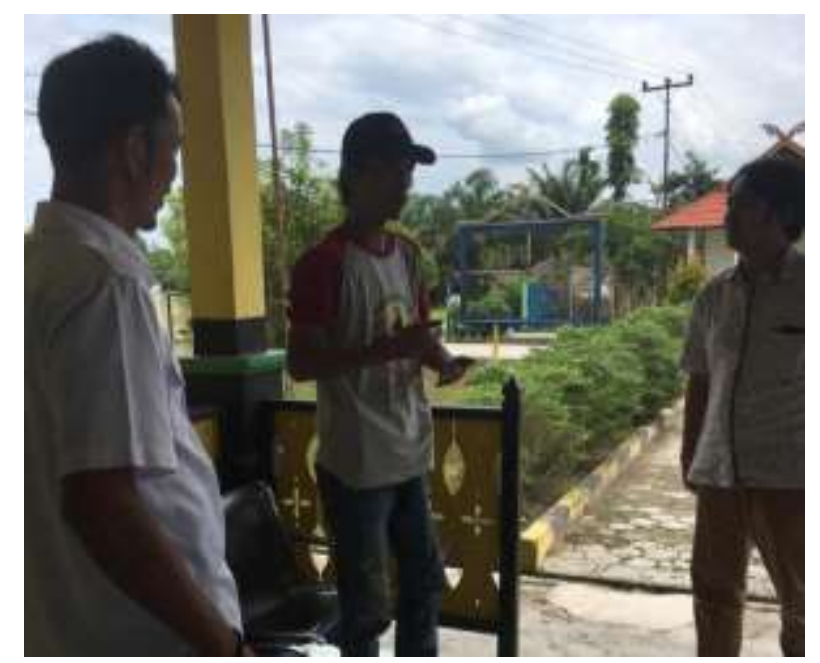

(c)

Gambar 2. Kunjungan ke BPDB Kabupaten Siak (a) Survey disalah satu lahan gambut(b) Wawancara dengan pihak MPA (c)

Setelah melakukan survey dan kunjungan, mahasiswa melakukan tugas KUKERTA untuk membuat karya sesuai dengan bidang ilmu masing-masing. Karena kegiatan KUKERTA dilaksanakan pada masa pandemi COVID-19, maka pengerjaan dilakukan dirumah masingmasing, dan terkait dengan koordinasi dilakukan secara daring (gambar 3a). Beberapa hasil karya mahasiswa KUKERTA yang membuat desain media terkait bahaya asap dapat dilihat pada gambar 3b dan gambar 3c. Selain itu, dua orang mahasiswa KUKERTA yang berasal dari program studi Teknik Informatika membantu dalam merakit alat telemetri dan mengembangkan aplikasi deteksi dini berbasis web (gambar $3 \mathrm{~d}$ dan gambar 3e). 


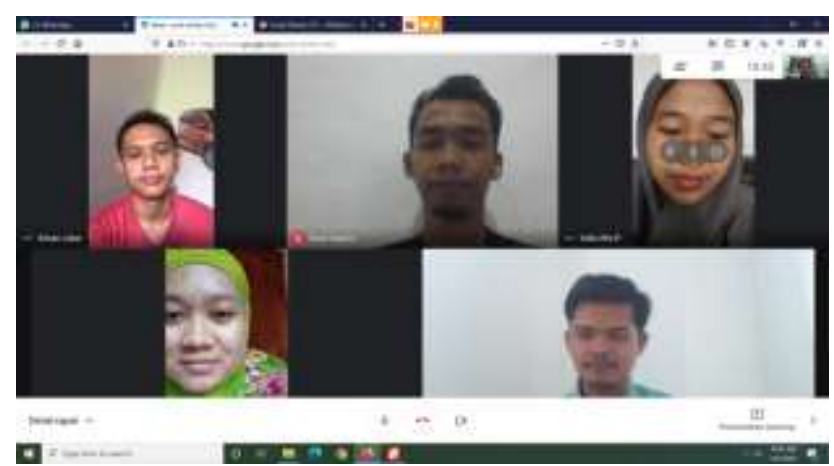

(a)

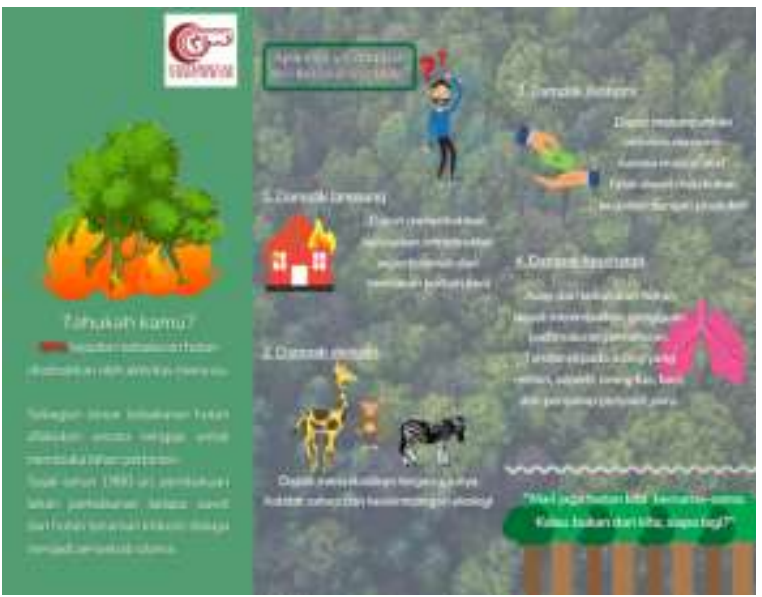

(b)

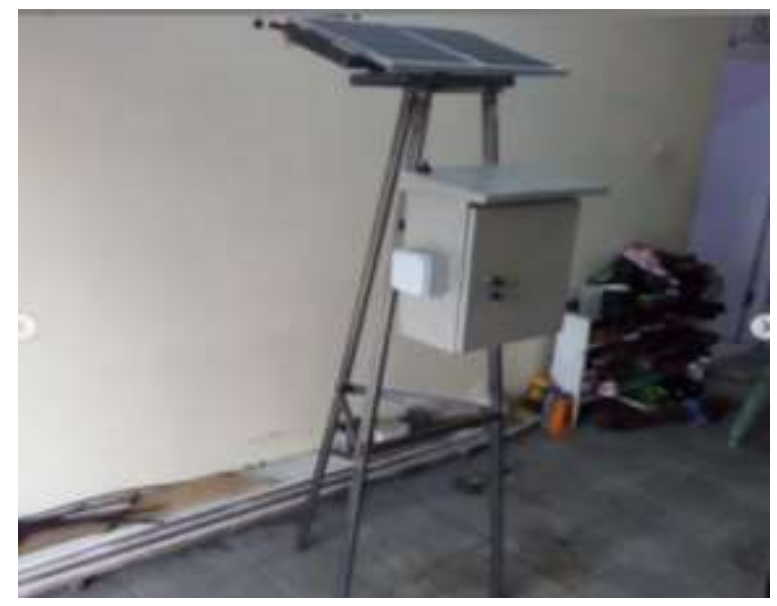

(d)

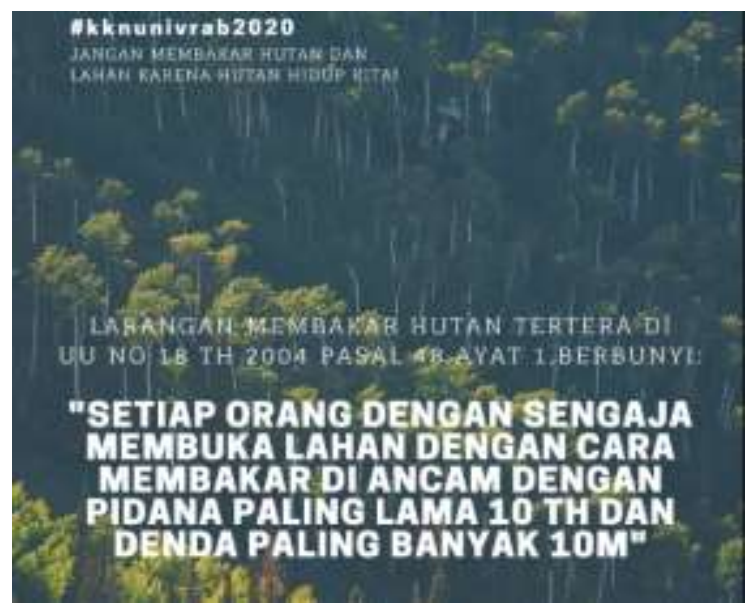

(c)

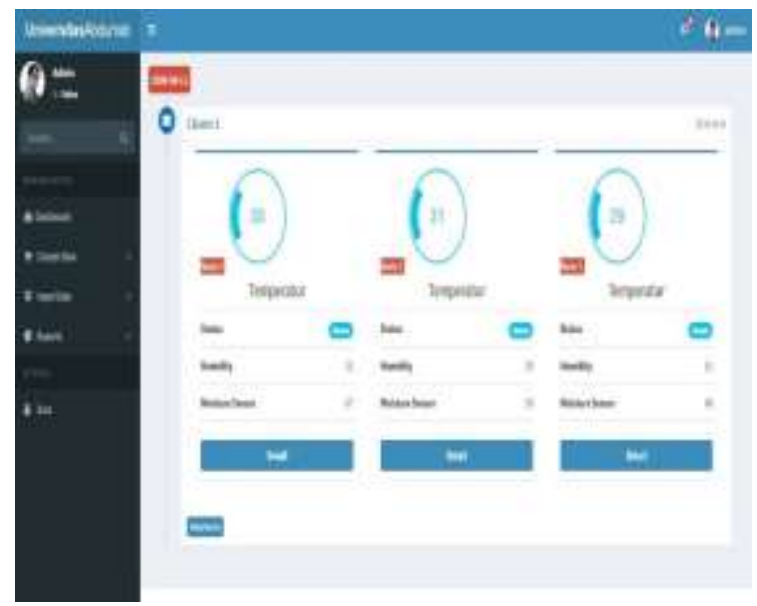

(e)

Gambar 3. Koordinasi via daring (a) desain media terkait bahaya asap (b) desain media terkait larangan membakar lahan (c) alat telemetri yang telah selesai dirakit (d) rancangan antarmuka aplikasi deteksi dini (e)

Hasil kerja dari mahasiswa KUKERTA kemudian dipresentasikan dikantor BPBD Siak (gambar 4a) yang disaksikan oleh pegawai BPBD, anggota Damkar, perwakilan Desa, dan Masyarakat Peduli Api (MPA). Selain itu alat yang telah selesai dirakit kemudian diletakkan pada lahan yang punya potensi menimbukan bencana kebakaran dan asap, serta diintegrasikan dengan aplikasi yang telah dibuat (gambar $4 \mathrm{~b}$ ). 


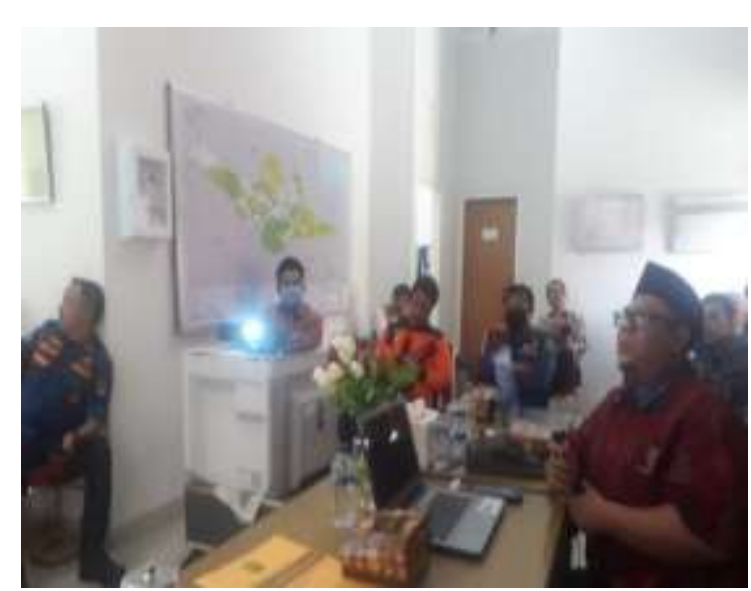

(a)

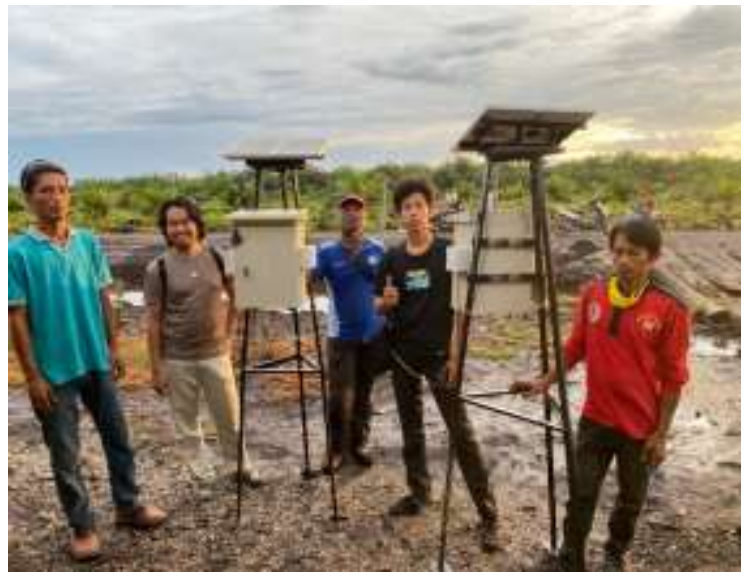

(b)

Gambar 4. Presentasi kegiatan dikantor BPBD Siak (a) Alat telementri yang diuji coba dan diintegrasikan dengan aplikasi deteksi dini (b)

Setelah selesai melakukan pemaparan dan presentasi, mahasiswa KUKERTA menyebarkan angket kepada para peserta kegiatan untuk mengetahui tingkat kepuasan dari Kegiatan KUKERTA yang telah dilaksanakan oleh Mahasiswa. Dari 30 peserta pengabdian, sebanyak $90 \%$ peserta (gambar 5) menyatakan puas atas penyampaian materi yang diberikan.

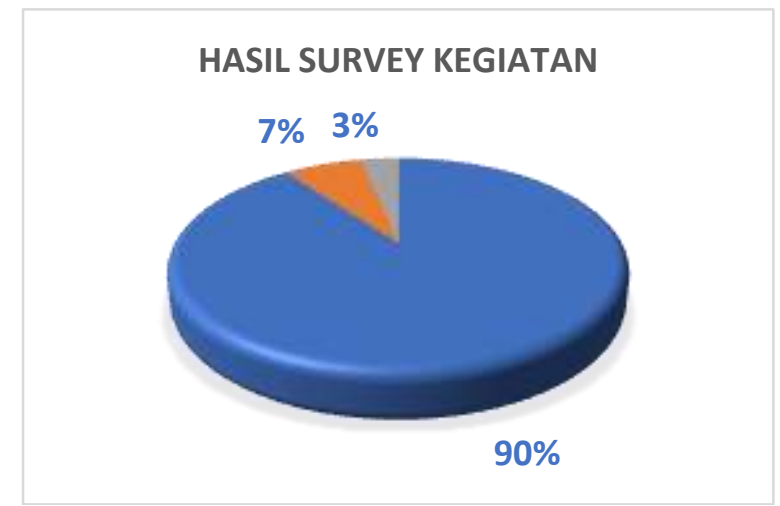

Gambar 5. Hasil survey kepuasan dari kegiatan KUKERTA

Kegiatan presentasi ini kemudian ditutup dengan sesi foto bersama seperti terlihat pada gambar 6 yang menandakan berakhirnya kegiatan KUKERTA terintegrasi mahasiswa Universitas Abdurrab tahun 2020.

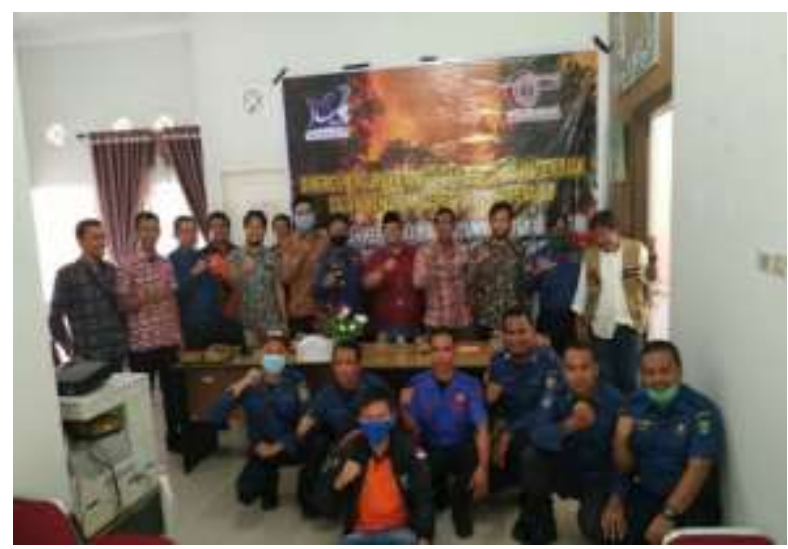

Gambar 6. Sesi foto bersama setelah acara 


\section{KESIMPULAN}

Daerah Siak khususnya desa Dayun merupakan salah satu daerah yang selalu terkena dampak bencana asap yang berasal dari kebakaran lahan. Melalui kegiatan KUERTA mahasiswa Universitas Abdurrab yang terintegrasi dengan kegiatan pengabdian Dosen dapat menjadi sarana bagi mahasiswa untuk dapat memecahkan masalah yang ada di Masyarakat sesuai dengan keilmuan yang dimiliki. Dengan keterbatasan pada masa pandemi COVID-19, program KUKERTA Universitas Abdurrab mampu menghasilkan karya bagi mitra pengabdian maupun ke masyarakat desa Dayun. Hasil dari kegiatan tersebut diantaranya media tentang bahaya asap bagi kesehatan, larangan membakar lahan, dan aplikasi peringatan dini. Pada saat ini, hasil dari kegiatan pengabdian telah dimanfaatkan oleh pihak desa dan BPBD, dan berdasarkan hasil dari survey kepuasan, kegiatan ini telah mendapatkan respon positif.

\section{UCAPAN TERIMA KASIH}

Penulis mengucapkan terima kasih kepada Universitas Abdurrab melalui Lembaga Penelitian dan Pengabdian Kepada Masyarakat (LPPM), BPBD Kabupaten Siak, Pemerintah Desa Dayun, dan segenap Masyarakat Desa Dayun atas dukungan dan tanggapannya terhadap kegiatan pengabdian dan KUKERTA ini.

\section{DAFTAR PUSTAKA}

Arisandi, D., Syamsuadi, A., Gafar, T. F., Hartati, S., \& Fajar, M. (2020a). Pembinaan Masyarakat Peduli Api Sebagai Bentuk Partisipasi Warga Desa Dayun Dalam Menangani Bencana Kebakaran Lahan. Ikraith-Abdimas, 3(3), 34-37.

Arisandi, D., Syamsuadi, A., Gafar, T. F., Hartati, S., \& Fajar, M. (2020b). Rancang Bangun Perangkat Telemetri Sebagai Deteksi Dini Kebakaran Hutan Di Desa Dayun Kabupaten Siak. IkraithAbdimas, 3(3), 7-11.

Badan Perencanaan Pembangunan Daerah Kabupaten Siak. (2014). Buku Profil Daerah Kabupaten Siak Tahun 2013. Siak.

Friscalia, D. (2016). Komunikasi Penyuluhan Manggala Agni Dalam Membina Masyarakat Peduli Api (Mpa) Di Desa Sungai Rawa Kabupaten Siak. Jom Fisip Unri, 3(2), 1-15.

Harahap, D. K., Yoza, D., \& Oktorini, Y. (2017). Strategi Pencegahan Kebakaran Hutan Dan Lahan Berdasarkan Persepsi Masyarakat Di Desa Dayun Kabupaten Siak. Jom Faperta Ur, 4(1), 1-11.

Jamaan, A., Yuliani, F., Adianto, A., \& Sadad, A. (2019). Penyuluhan pencegahan kebakaran hutan dan lahan pada kawasan gambut Kecamatan Dayun Kabupaten Siak Sri Indrapura. Unri Conference Series: Community Engagement, 1, 470-476. https://doi.org/10.31258/unricsce.1.470-476

Meiwanda, G. (2016). Kapabilitas Pemerintah Daerah Provinsi Riau: Hambatan dan Tantangan Pengendalian Kebakaran Hutan dan Lahan. Jurnal Ilmu Sosial Dan Ilmu Politik, 19(3), 251. https://doi.org/10.22146/jsp.15686

Mustafa, I. R., Abdillah, M. B., Winata, N. R., Pratama, R., Rosi Isnanda, Putra, T. D. A., \& Sulistyo, W. D. (2020). Edukasi Gerakan Siswa Anti Narkoba" (Geswana) Era Desrupsi 4.0 di Smp Wahid Hasyim Malang. Dinamisia: Jurnal Pengabdian Kepada Masyarakat, 3(2), 189-197. https://doi.org/10.31849/dinamisia.v3i2.3214

Nasution, A., Mubarak, M., \& Zulkifli, Z. (2013). Studi Emisi C02 Akibat Kebakaran Hutan Di Provinsi Riau (Studi Kasus Di Kabupaten Siak). Bumi Lestari Journal of Environment, 13(1), 2736.

Naufal, M., Waluyati, L. R., \& Darwanto, D. H. (2019). Kinerja Usahatani Kelapa Sawit Lahan Gambut di Desa Dayun Kabupaten Siak. Jurnal Teknosains, 9(1), 77. https://doi.org/10.22146/teknosains.38976

Nugraha, R. P., Fauzi, A., \& Ekayani, M. (2019). Analisis Pendapatan Usaha Pertanian Dan Peternakan. Jurnal Ekonomi Pertanian, Sumberdaya dan Lingkungan (Journal of Agriculture, 
Resource, and Environmental Economics ), 2(2), 1-11.

Riau Pos. (2019). 22 Ribu Warga Terpapar ISPA. Retrieved from Riau Pos website: https://riaupos.jawapos.com/pekanbaru/27/08/2019/207275/22-ribu-warga-terpaparispa.html

Saharjo, B. H., Syaufina, L., Nurhayati, A. D., Putra, E. I., Waldi, R. D., \& Wardana. (2018). Pengendalian Kebakaran Hutan dan Lahan di Wilayah Komunitas Terdampak Asap. In IPB Press (Vol. 15).

Sutisna, S., Hikmatin, M., \& Utami, D. P. (2018). Pemberdayaan Masyarakat Melalui Peningkatan Mutu Pendidikan, Ekonomi Dan Kesehatan Studi Kasus Desa Situ Ilir. Abdi Dosen: Jurnal Pengabdian Pada Masyarakat, 02(04), 417-425.

Syamsuadi, A., Arisandi, D., Gafar, T. F., Trisnawati, L., Hartati, S., \& Anugerah, M. F. (2020). Peningkatan Kewaspadaan Bencana Asap Di Kecamatan Dayun Kabupaten Siak. Community Development Journal: Jurnal Pengabdian Masyarakat, 1(2), 48-51. 